\title{
THE URAL OWL, STRIX URALENSIS MACROURA, IN SLOVENIA: AN OVERVIEW OF CURRENT KNOWLEDGE ON SPECIES ECOLOGY
}

\begin{abstract}
In Slovenia the Ural Owl, Strix uralensis macroura, is on the north-western limit of its distribution with an estimated population size of 400-700 breeding pairs. The densities of territories range between 0.9 to 13.4 territories per $10 \mathrm{~km}^{2}$, and the highest densities are reached in montane forests of the southern Dinaric region. In the forests with dominant deciduous trees, e.g. Fagus sylvatica and Quercus robur, the breeding densities are significantly higher than in the forests with a higher proportion of coniferous trees, e.g. Picea abies. The species does not select specific altitude and throughout Slovenia it occurs between 150 and $1600 \mathrm{~m}$ a.s.l. Most natural nests were found in tree holes or semi-holes (56\%) and on the tree stumps $(20 \%)$. Breeding begins between 15 March to 21 June with median clutch sizes of 3.0 eggs per nest. In the brood there are 2 young and 1.5 young are fledged in median. At present $75 \%$ of nests produce at least one young. Voles and Mice are the most frequent prey in the diet, but the Fat Dormouse, Glis glis, seems to have very important role in the post-breeding period. As a top predator, the Ural Owl influences also the distribution of other owl species in the guild through direct predation or competitive exclusion. However, it could have also a positive indirect effect on smaller species, e.g. Tengmalm's Owl, Aegolius funereus, which are tolerated within Ural Owl territories, and are able to extend their distribution due to exclusion from certain areas of the Tawny Owl, Strix aluco, by the Ural Owl.
\end{abstract}

Key words - Strix uralensis macroura, Slovenia, distribution, breeding density, habitat, breeding biology, interactions.

Riassunto - L'Allocco degli Urali, Strix uralensis macroura, in Slovenia: una visione d'insieme delle attuali conoscenze dell'ecologia della specie.

In Slovenia l'Allocco degli Urali raggiunge il limite nord-occidentale della distribuzione della ssp. macroura, con una popolazione stimata di 400-700 coppie nidificanti. La densità dei territori si attesta tra 0,9-13,4 territori per $\mathrm{km}^{2}$, e le maggiori densità vengono raggiunte nelle foreste montane della regione dinarica meridionale. Nelle foreste con essenze decidue dominanti, come Fagus sylvatica e Quercus robur, le densità riproduttive sono significativamente maggiori che nelle foreste con una più alta proporzione di conifere, come Picea abies. La specie non seleziona una specifica altitudine e in tutta la Slovenia si può trovare tra i 150 e i 1600 metri di quota. I nidi più frequenti sono stati trovati in buchi d'albero o semi-cavità (56\%) e sui ceppi di albero $(20 \%)$. La riproduzione inizia tra il 15 marzo e il 21 giugno con covate medie di 3,0 uova per nido. Nella

1 National Institute of Biology, Večna pot 111, SI-1000 Ljubljana, Slovenia

E-mail: al.vrezec@nib.si

2 DOPPS-BirdLife Slovenia, Tržaška cesta 2 (p.p. 2990), SI-1000, Ljubljana, Slovenia

E-mail: tomaz.mihelic@dopps-drustvo.si 
nidiata vi sono 2 piccoli, e in media si involano 1,5 giovani. Attualmente il $75 \%$ dei nidi dà luogo ad almeno un piccolo. Le prede più frequenti sono arvicole e topi, ma il Ghiro, Glis glis, sembra avere un ruolo molto importante nella composizione della dieta nel periodo post-riproduttivo. Come superpredatore, l'Allocco degli Urali influenza anche la distribuzione delle altre specie di Strigiformi nella gilda mediante predazione diretta o esclusione competitiva. Tuttavia può avere anche un effetto indiretto positivo su specie di mole minore, per esempio la Civetta capogrosso, Aegolius funereus, che viene tollerata all'interno dei territori dell'Allocco degli Urali, e che può estendere la sua distribuzione grazie all'esclusione da certe aree dell'Allocco comune, Strix aluco, da parte dell'Allocco degli Urali.

Parole chiave - Strix uralensis macroura, Slovenia, distribuzione, densità riproduttiva, biologia riproduttiva, interazioni.

\section{Introduction}

Although Ural Owl, Strix uralensis, is a typical boreal species, two isolated southern populations are known, one on the mountains of China, described as S. $u$. davidi (ShERZINGER \& FANG, 2006), and the other on Central and SE European mountains, described as S. u. macroura (KoHL, 1977). Both are considered as glacial relics (Mikкola, 1983). The $S . u$. macroura is the largest Ural Owl subspecies and is nowadays confined mainly to the Carpathians and Dinaric Alps. In the past it became extinct in more western regions (SCHERZINGER, 2006). The total population of macroura subspecies was recently estimated at roughly 6500 breeding pairs (MeBs, 2007). In the Dinaric part of its distribution the Ural Owl is quite well known in Slovenia and Croatia (e.g. Minelič et alii, 2000; VREzEC \& TuTiš 2003; TuTiš et alii, 2007), but data are very scarce from Bosnia and Herzegovina, Serbia, and Montenegro (Puzovič et alii, 2003; KotrošAn \& PAPES, 2007). In Slovenia, the Ural Owl population reaches the eastern Alps, and some territorial or breeding pairs were found also in Italy and Austria (Feldner et alii, 2006; Genero \& Benussi, 2007).

The tradition of Ural Owl research in Slovenia is quite long-lasting, with the first scientific report of the species dated at the end of $18^{\text {th }}$ century by Scopoli (1769) and HACQUeT (1791) under the names of Strix sylvestris and Strix nigra (VREZEC et alii, 2007). During the $19^{\text {th }}$ century several data about Ural Owl occurrence were collected, especially during the winter period, and from numerous published data we can conclude that even then the species was not rare in Slovenia (see e.g. PonEBŠEK, 1917). However, detailed breeding and winter distribution was provided at the end of $20^{\text {th }}$ century (Sovinc, 1994; Geister, 1995), when also systematic population and ecological studies were carried out (see references below). Today, the Ural Owl biology and ecology is intensively studied in Slovenia, and therefore the aim of this paper is to summarize published and unpublished studies on the species distribution, population size, habitat selection, breeding biology, and its significance as a top predator in a forest ecosystem. 


\section{Methods}

In order to investigate the Ural Owl breeding distribution in Slovenia, we have collected data on recent observations of the species during its breeding period. In the last 15 years, several population surveys have been conducted. Most of them used a point count method with playback stimulation to record territorial responses by owls (e.g. Benussi \& Genero, 1995; Vrezec, 2000a; Prešern \& KoheK, 2001; AmbrožIč, 2002). The survey method is based on counting hooting owls at survey points that are about 1000 metres apart. At each point the owls are recorded at a distance of $500 \mathrm{~m}$, and therefore an effective survey area of $0.78 \mathrm{~km}^{2}$ around each point is defined for calculating the density of territories (VREZEC, 2003). All population surveys were done in the breeding period between March and June, when Ural Owls are particularly vociferous (VREZEC, 2000b; Kонек, 2005). During systematic surveys, habitat characteristics of occupied territories were recorded and tested with Mann-Whitney $\mathrm{U}$ and $\chi^{2}$ tests to establish Ural Owl habitat preferences (AMBROžIč, 2004; VREZEC \& Tome, 2004a). More attention was placed also on the Ural Owl altitudinal distribution in Slovenia on a local and national scale (e.g. Tome, 1996; Minelič et alii 2000; AmBRožIČ, 2002). Systematic surveys were conducted in different regions rising from lowlands to the tree line. The relative densities of owl territories were calculated for each 200 metre-altitudinal belt. With the non-parametric Spearman correlation coefficient, we tested to see if the density changed across the elevation.

To date, the breeding biology of the Ural Owl in Slovenia was known only from occasionally and rarely found nests (PERUŠEK, 1998; VREZEC \& Kонек, 2002). With systematic surveys of nest boxes, several new data about clutch and brood size and breeding success were obtained (VREZEC, 2007a, unpubl.). The studies on the role of the Ural Owl as top predator in forest ecosystems dealt with the species' diet (VREZEC, 2000c, 2001) and its intraguild interactions with other owl species (MinELIČ, 2002; VREZEC \& Tome, 2004a, 2004b; VRH \& VREZEC, 2006). We have summarized the main findings in the discussion.

\section{Results and discussion}

The estimated breeding population size of the Ural Owl in Slovenia ranges from 400 to 700 pairs (VREZEC \& MinELIČ, 2002). Since forests cover at least 58\% of Slovenia (REJEC BRANCELJ \& KuŠAR, 2006) there are good conditions for the Ural Owl (Fig. 1).

In the breeding period, the species is very common in the southern Dinaric region with local densities ranging from 1.0 to 13.4 territories/10 $\mathrm{km}^{2}$ (VReZec 2003; Rubinić et alii, 2007). In the northern Alpine region, 


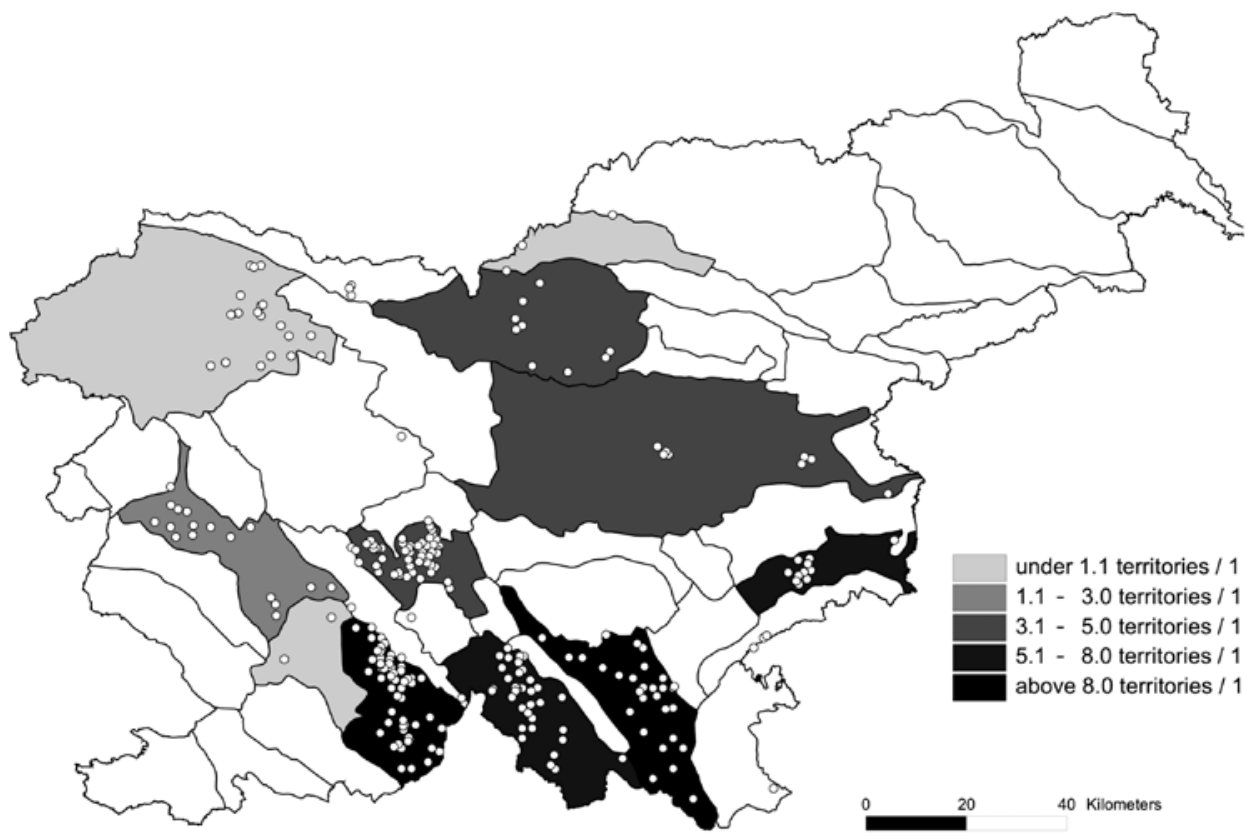

Fig. 1 - Distribution of the Ural Owl Strix uralensis in Slovenia with marked density estimations for better-searched regions.

the densities are on average lower, ranging from 0.9 to 4.6 territories / 10 $\mathrm{km}^{2}$ (SveTLIČIČ \& KLADNIK, 2001; VREZEC, 2007a), probably due to the differences in forest structure. However, the densities reached in Slovenia are among the highest known for the species, similar to Poland and Slovakia, but much higher compared to northern regions (e.g. VREZEC, 2003; KRIŠTIN et alii, 2007).

In Slovenia the Ural Owl was found breeding in coniferous (i.e. Adenostyloglabrae-Piceetum) as well as in mixed (i.e. Omphalodo-Fagetum s. lat.) and deciduous forest types (i.e. Pseudostellario-Quercetum roboris). However, in the forests with dominant deciduous trees, e.g. Fagus sylvatica and Quercus robur, the breeding densities (median 3.5 territories $\left./ 10 \mathrm{~km}^{2}\right)$ were found to be significantly higher $(\mathrm{U}=2.00, \mathrm{p}<0.05)$ than in the forests with a higher proportion of coniferous trees, e.g. Picea abies (median 1.0 territories $/ 10 \mathrm{~km}^{2}$ ). A more detailed study on Ural Owl habitat preferences was conducted in a montane dinaric Beech forest with Fir Omphalodo-Fagetum s. lat., but no siginificant preferences were confirmed (AмBrožIč, 2004; VREZEC \& Tome, 2004a). On the other hand, differently from its close relative, the Tawny Owl, Strix aluco, the Ural Owl tends to avoid human settlements and their vicinity during the breeding period (VREZEC \& ToMe, 2004b). Compared to montane forests in lowlands 
Ural Owls are rare and confined to scattered lowland (sub)populations. This is probably the consequence of human impact since large forest complexes in the old growth phase with thick-trunk trees were mostly cut down in the past. Only some Oak forests were preserved in the eastern part of Slovenia, where Ural Owls breed at high density (7.8 territories/10 $\mathrm{km}^{2}$, Ambrožič \& Vrezec, in prep.). This data indicates that in lowlands, Ural Owls can breed at densities as high as in montane forests (Fig. 2), because the breeding density does not vary significantly according to altitude (Spearman's $\mathrm{r}=-0.24, \mathrm{p}>0.50$ ). Therefore, the Ural Owl may be considered a very tolerant species as far as altitudinal distribution is concerned (Tome, 1996), because it may be found from lowlands up to the tree line, 150-1600 m a.s.l. (MineLič et alii, 2000).

So far, only few natural nests of Ural Owls are known for Slovenia $(n=23)$, and the majority of them were located in tree holes or semi-holes $(56 \%)$ or at the top of tree stumps $(20 \%)$. The abundance of old trees providing large holes for breeding is a crucial factor for the species (LõHMUs, 2003). The most common breeding trees in Slovenia are Fagus sylvatica, Acer pseudoplatanus and Picea abies, occasionally Abies alba, Quercus robur and Q. petraea (VReZec, 2007a). Only few nests (16\%) were found in abandoned nests of raptors (e.g. Common Buzzard, Buteo buteo, Honey Buzzard, Pernis apivorus) or Black Stork, Ciconia nigra, one at the ground and one at the hunters' hide (Perušek, 1998; Vrezec \& KoheK, 2002). Data on the breeding biology of the species were collected mainly from the nest boxes, although they were less frequently occupied than, for example, in Finland (SAUROLA, 2007). Around $24 \%$ of available nest boxes in montane forests have been occupied so far. There were 2 to 4 eggs laid in the nest boxes, 1.5 young per nest were fledged, and $75 \%$ of nests produced at least one young (Tab. I). In general, in montane forests of Slovenia the first eggs

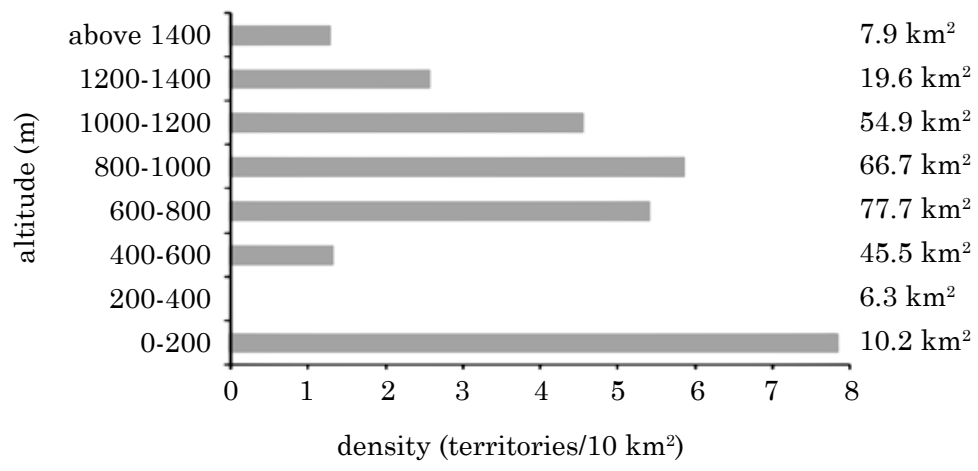

Fig. 2 - Density changing of the Ural Owl, Strix uralensis, according to the altitudinal distribution; survey areas sizes are shown at each altitudinal belt (joint data of systematic owl surveys; $\mathrm{N}_{\text {areas }}=15, \mathrm{~N}_{\text {survey points }}=368, \mathrm{~N}_{\text {owl territories }}=126$ ). 
Tab. I - Clutch and brood size, number of fledged young, and breeding success of the Ural Owl, Strix uralensis, in the nest boxes from montane forests in Slovenia.

\begin{tabular}{lccc}
\hline & Clutch (eggs per nest) & Brood (young per nest) & Fledged (young per nest) \\
\hline Median & 3.0 & 2.0 & 1.5 \\
Minimum & 2 & 0 & 0 \\
Maximum & 4 & 3 & 2 \\
\hline Breeding success (\% of eggs) & & $51.7 \%$ & $40.0 \%$ \\
Breeding success (\% of nests) & & $77.8 \%$ & $75.0 \%$ \\
N (nests) & 10 & 9 & 8 \\
\hline
\end{tabular}

in Ural Owl nests were found from 15 March to 21 June (VRezec, 2007a), but in the lowlands, breeding can already start in February (VREzeC \& TuTiš, 2003).

The Ural Owl is predominantly a small mammal predator, and the proportion of other prey, birds, amphibians and insects, is very low in its diet, no more than $11.5 \%$ in Slovenia (VREZEC, 2007a). The proportion of alternative prey species increases in the pre-breeding and breeding period, and decreases in the post-breeding period. This may be due to the lack of main prey species, small mammals, in the environment in early spring.

The main Ural Owl prey are voles, Arvicolidae (36.8\%) and mice, Muridae (23.3\%), but in the post-breeding period the Fat Dormouse, Glis glis, is the dominant prey species, representing locally $58.8 \%$ by number and $93.9 \%$ by biomass of the species preyed on (Vrezec, 2000c). The late occurence of the Fat Dormouse in the diet is due to the habit of this small mammal, which attains its population peak in late summer (KRYšTUFEK \& FLAJŠMAN, 2007).

As a top predator, the Ural Owl influences also the distribution of other owl species in the guild, and smaller owls, e.g. Long-eared Owl, Asio otus, could be preyed upon (VREzEc, 2001). Strong competition between Ural and Tawny Owls has been detected in montane forests, where the larger Ural Owl excludes competitively the smaller Tawny Owl from its territory (VRezec \& Tome, 2004b). In mixed montane forests in the Dinaric region, a third owl species, the Tengmalm's Owl, Aegolius funereus, is present. Territories of this species largely overlap Ural Owl but not Tawny Owl territories (Vrezec \& Tome, 2004a). Thus, the Tengmalm's Owl may extend its distribution due to exclusion of the Tawny Owl by the Ural Owl from certain areas. This effect may be due to a positive indirect interaction between the largest and the smallest predators in the guild, i.e. a specific type of commensalisms, which has already been described for other species (VRezec, 2007b). The same thing happens to Scops Owls, Otus scops, and Eagle Owls, Bubo bubo, in the Val Rosandra (GALEOTTI \& GARIBOLDI, 1994). 
Ringraziamenti - We would like to thank Dr Davorin Tome for valuable comments on the manuscript, and Enrico Benussi and Kajetan Kravos for the invitation to participate at XIV CIO in Trieste.

\section{BIBLIOGRAFIA}

АмBRožıč Š., 2002 - Sove Trnovskega gozda: gostota, višinska razširjenost in medvrstni odnosi Acrocephalus, 23: 129-134.

АмвRоžıč Š., 2004 - Razširjenost štirih vrst sov (Strigidae) v Trnovskem gozdu v odvisnosti od nekaterih ekoloških dejavnikov - Graduation Thesis, University of Ljubljana, Ljubljana.

Benussi E. \& Genero F., 1995 - L’Allocco degli Urali (Strix uralensis macroura) nel Trnovski gozd (Slovenia). Censimento in un'area campione - Suppl. Ric. Biol. Selvaggina, 22: 563-568.

Feldner J., Rass P., Petutsching W., Wagner S., Malle G., Buschenreiter R.K., Wiedner P. \& Probst R., 2006 - Avifauna Kärntens, Die Brutvögel - Naturwissenschaftlicher Verein für Kärnten, Klagenfurt.

Galeotti P. \& Gariboldi A., 1994 - Territorial Behaviour and Habitat Selection by the Scops Owl Otus scops in a Karstic Valley (NE Italy). In: Meyburg B.U. \& Chancellor R.D. (eds). Raptor Conservation Today - WWGBP, Pica Press, pp. 501-505.

GeISTER I., 1995 - Ornitološki atlas Slovenije - DZS, Ljubljana.

Genero F. \& Benussi E., 2007 - New data and status of Ural Owl (Strix uralensis) in Italy. In: Müller J., Scherzinger W. \& Moning C. (eds). European Ural Owl workshop - Bavarian Forest National Park, Grafenau, pp. 36-41.

Hacquet B., 1791 - Neueste physikalisch-politische Reisen in den Jahren 1788 - 95 durch die Dacischen und Sarmatischen oder Nördlichen Karpathen. 2. Theil - Kaspische Buch, Nürnberg.

Kонек K., 2005 - Dnevna in sezonska dinamika oglašanja kozače (Strix uralensis) - Graduation Thesis, University of Ljubljana, Ljubljana.

KонL S., 1977 - Über die taxonomische stellung der Südost-europäischen Habichtskäuze, Strix uralensis macroura Wolf, 1810 - Muzeul Brukenthal, Studii si Comunicäri - St. nat., 21: 309-334.

Kotrošan D. \& PAPes M., 2007 - Popis ptica zabilježenih u Bosni i Hercegovini od 1888. do 2006. Godine - Bilten mreže posmatrača ptica u Bosni i Hercegovini, 3(3): 9-38.

Krištin A., Mihok J., Danko Š., Karaska D., Pačenovsky S., Saniga M., Bodova M., Balazs C., Š́tNar K., Kornan J. \& OleKŠAK M., 2007 - Distribution, abundance and conservation of the Ural Owl Strix uralensis in Slovakia. In: Müller J., Scherzinger W. \& Moning C. (eds). European Ural Owl workshop - Bavarian Forest National Park, Grafenau, pp. 9-15.

Kryštufek B. \& Flajšman B., 2007 - Polh in človek - Ekološki forum LDS, Liberalna akademija, Ljubljana.

LõHmus A., 2003 - Do Ural owls (Strix uralensis) suffer from the lack of nest sites in managed forests? - Biological Conservation, 110: 1-9.

Mebs T., 2007 - Summary on population and conservation status of the Ural Owl (Strix uralensis) in Europe. In: Müller J., Scherzinger W. \& Moning C. (eds). European Ural Owl workshop - Bavarian Forest National Park, Grafenau, pp. 6-7.

Minelič T., 2002 - Prehrana velike uharice Bubo bubo v jugozahodni Sloveniji - Acrocephalus, 23 (112): 81-86.

Mihelič T., Vrezec A., Perušek M. \& Svetličıč J., 2000 - Kozača Strix uralensis v Sloveniji - Acrocephalus, 21: 9-22.

Mikкola H., 1983 - Owls of Europe - T \& AD Poyser, London.

Perušek M., 1998 - Gnezdenje kozače Strix uralensis v kočevsko-ribniških gozdovih - Acrocephalus, 19 (89): 99-103.

Ponebšek J., 1917 - Naše ujede, I. del: Sove - Carniola, Muzejsko društvo za kranjsko, Ljubljana.

Prešern J. \& KoHek K., 2001 - Popis kozače Strix uralensis macroura na Javornikih - Acrocephalus, 22 (108): 167-169.

Puzović S., Simić D., Saveljić D., Gregelj J., Tucakov M., Stojnić N., Hulo I., Ham I., Vizi O., Šćiban M., Ružić M., Vučanović M. \& Jovanović T., 2003 - Ptice Srbije i Crne Gore - veličina gnezdilišnih populacija i trendovi: 1990-2002 - Ciconia, 12: 35-120. 
Rejec BRANCELJ I. \& KuŠAR U. (eds), 2006 - Kazalci okolja 2005 - Ministrstvo za okolje in prostor, Agencija RS za okolje, Ljubljana.

Rubinić B., Božıč L., Denac D. \& Kmecl P., 2007 - Poročilo monitoringa izbranih vrst ptic na posebnih območjih varstva (SPA) - DOPPS-BirdLife Slovenia, Ljubljana.

SAURola P., 2007 - Finnish Ural Owls (Strix uralensis): an overview on population parameters. In: Müller J., Scherzinger W. \& Moning C. (eds). European Ural Owl workshop - Bavarian Forest National Park, Grafenau, pp. 42-49.

Scherzinger W. \& FAng Y., 2006 - Field observations of the Sichuan Wood Owl Strix uralensis davidi in western China - Acrocephalus, 27 (128/129): 3-12.

Scopoli I.A., 1769 - Annus I. Historico-Naturalis. Descriptiones Avium-Sumtib - Christ. Gottlob Hilscheri, Lipsiae.

Sovinc A., 1994 - Zimski ornitološki atlas Slovenije - Tehniška založba Slovenije, Ljubljana.

SvetLIČč J. \& KLADNIK T., 2001 - Razširjenost in gostota kozače Strix uralensis na Krašici v Savinjskih Alpah - Acrocephalus, 22 (108): 155-158.

Tome D., 1996 - Višinska razširjenost sov v Sloveniji - Acrocephalus, 17: 2-3.

Tutiš V., Radović D., Ciković D. \& Barišić S., 2007 - Distribution, density and habitat relationships of the Ural owl Strix uralensis in Croatia. In: World Owl Conference, 31 October - 4 November 2007, Groningen.

VRezec A., 2000a - Popis kozače Strix uralensis na Ljubljanskem vrhu - Acrocephalus, 21 (98/99): $39-41$.

VREZEC A., 2000b - Vpliv nekaterih ekoloških dejavnikov na razširjenost izbranih vrst sov (Strigidae) na Krimu - Graduation Thesis, University of Ljubljana, Ljubljana.

VRezeC A., 2000c - Prispevek k poznavanju prehrane kozače Strix uralensis macroura na Kočevskem - Acrocephalus, 21 (98/99): 77-78.

VREzec A., 2001 - Winter diet of one female Ural Owl (Strix uralensis) at Ljubljansko barje (central Slovenia) - Buteo, 12: 71-76.

Vrezec A., 2003 - Breeding density and altitudinal distribution of the Ural, Tawny, and Boreal Owls in North Dinaric Alps (central Slovenia) - J. Raptor Res., 37 (1): 55-62.

VRezec A., 2007a - The Ural Owl (Strix uralensis macroura) - Status and overview of studies in Slovenia. In: MÜller J., Scherzinger W. \& Moning C. (eds). European Ural Owl workshop - Bavarian Forest National Park, Grafenau, pp. 16-31.

VREZEC A., 2007b - Competitive exclusion and indirect interactions in the forest owl guild. In: World Owl Conference, 31 October - 4 November 2007, Groningen.

VRezec A. \& Конек K., 2002 - Nekaj gnezditvenih navad kozače Strix uralensis v Sloveniji Acrocephalus, 23 (115): 179-183.

VRezec A. \& Minelič T., 2002 - Distribution, densité et comportements de la Chouette de l'Oural, Strix uralensis macroura en Slovenie, durant la periode de nidification. In: JuILLARD M. (ed.). $41^{e}$ Colloque interregional d'Ornithologie, Porrentruy - Suisse. Société des Sciences naturelles du Pays de Porrentruy (SSNPP), Porrentruy, pp. 35-37.

Vrezec A., Smole J. \& VRh VRezec P., 2007 - Descriptions of European owl species by Scopoli (1769): a problem of overlooked European owl names? In: World Owl Conference, 31 October - 4 November 2007, Groningen.

VREzec A. \& Tome D., 2004a - Habitat selection and patterns of distribution in a hierarchic forest owl guild - Ornis Fennica, 81: 109-118.

Vrezec A. \& Tome D., 2004b - Altitudinal segregation between Ural Owl Strix uralensis and Tawny Owl S. aluco: evidence for competitive exclusion in raptorial birds - Bird Study, 52: 264-269.

VReZec A. \& Tutiš V., 2003 - Characteristics of North Dinaric Ural Owl (Strix uralensis macroura) population. In: SchwerdTFEger O. \& SchwerdTFEger J. (eds). Ecology and Conservation of European Owls. $4^{\text {th }}$ Meeting of European Owl-Experts, Dornbirn, pp. 75.

VRh P. \& VRezEC A., 2006 - Interspecific territorial vocal activity of the Ural Owl (Strix uralensis) towards Tawny Owl (Strix aluco), sympatric owl competitor: a playback experiment Razprave IV. razreda $S A Z U, 47$ (3): 99-105. 